\title{
Visual Interface Design Innovation: Citizens' Perception of Financial Administration Applications
}

\author{
Tereza Zichová \\ Corresponding author: Tereza Zichová (tereza.zichova@vse.cz)
}

Faculty of Informatics and Statistics, Prague University of Economics and Business, W. Churchill Sq. 1938/4, 13067 Prague 3, Czech Republic

\begin{abstract}
The paper deals with an analysis and evaluation of an innovative visual design of the Czech Financial Administration application, which was launched in order to solve needs arising from the COVID-19 pandemic. The Financial Administration had not made use of information technologies for several years, which had prevented the streamlining of public services offered to taxpayers. The aim of the study is to compare the perception of the visual interface design of two Financial Administration applications: (a) the Tax Portal - launched before the pandemic, and (b) the application for the provision of a compensation bonus for self-employed - launched during the pandemic. The research is based on a sequential mixed method design, where findings from a focus group and an interview are used to define relevant properties of web design to be evaluated in a questionnaire survey. The difference between variables regarding the perception of the Financial Administration applications is determined using a paired t-test. The results show that the new application has brought a significant change in the appearance of the interface design. Positive results of the Financial Administration's innovative approach can be beneficial for future development of different e-government projects.
\end{abstract}

\section{Keywords}

e-Administration; COVID-19 innovation; Czech financial administration; e-Governance; e-Government innovation; Visual interface design. 


\section{Introduction}

The outbreak of the coronavirus crisis has brought many challenges to society. As stated by the Czech Minister of Industry and Trade at the International Conference Digital Czechia 2021, due to the crisis, it was necessary to change the values, priorities, and solutions in the digitization plan (Havlíček, 2021). To the government and ministries, the crisis has brought many lessons in the field of digitization. There was a need to react flexibly to the situation and to build new systems on a green field. In recent years, the Czech Financial Administration had not paid considerable attention to the development of its information interface towards users. After the outbreak of the coronavirus, however, the public institution had to seek solutions to the situation in a very short time (Petráček, 2021). It turned out that digitization tools prepared before the crisis were not usable and that it was necessary to come up with a faster and more effective solution. Thus, a new application for a self-employed compensation bonus was created.

In an evaluation of overall tax complexity, the Czech Republic system was ranked the fourth most complex in Europe in January 2021. The tax complexity index reflects the complexity of the tax law and tax framework (Hoppe et al., 2019). According to an evaluation of digital public administration services, the Czech Republic ranked even 21st out of all 28 countries of the European Union in 2019 (eGovernment and Trust, 2020). For these reasons as well, it is necessary to assess whether citizens perceive the innovative approach in financial e-administration as positive and discuss its possible application to other government-citizen websites. Two different visual interface designs of the Financial Administration applications are compared by citizens in this study: (a) the Tax Portal - launched before the pandemic, and (b) the application for the provision of a compensation bonus for self-employed (so-called "twentyfive for self-employed persons") - launched during the first months of the pandemic in the Czech Republic in 2020 .

The aim of the paper is to compare the perception of the visual interface design of the Financial Administration's applications offered before the pandemic and developed during the pandemic. To assess the impact of design perception on users, it was first necessary to select the features that users would require from Financial Administration applications. Due to the specificity of the Czech tax system and the cultural specifics of citizens, these characteristics were determined by a qualitative survey instead of using established instruments for evaluating the new system. The research is based on a sequential mixed method design, where findings from a focus group and an interview are used to define relevant properties of web design to be evaluated in a questionnaire survey. The difference between variables regarding the perception of the Financial Administration applications is determined using a paired t-test.

\section{Current State}

The COVID-19 pandemic has had a significant impact on all industries around the world. It carries with it the burden of many losses, crises and collapses of systems, as well as challenges, solidarity and a search for new solutions. The possibility of doing business online and accessing all related public transactions online became crucial during the pandemic. In the area of innovation in electronic administration, the Czech Financial Administration and the related institutions responded very flexibly, helpfully and promptly to the acute need for online communication and use of information technologies (Havlíček, 2021).

Understanding citizens' design preferences regarding applications for meeting their civic responsibilities is very important for the state. Public institutions should constantly improve their systems and motivate people to use them. The government should provide high-quality and enhanced user-friendly e-services (Barnes and Vidgen, 2004) that increase ease and e-participation (Kumar et al., 2007). A positive perception of citizens helps with the implementation and willingness to use the new application (Abu-Shanab and Harb, 2019). Technology acceptance was needed, for example, for the newly developed public application 
eMask (eRouška in Czech) for voluntary detection and reporting of contact people infected with the COVID-19 virus. The paper results confirm the theories of basic user principles of design and thus help to understand their influence on user perception.

The groups of users of the e-government system are so diverse that it is necessary to pay attention to a thorough evaluation not only of their technical capabilities, but also of their know-how, experience and needs (Wimmer and Holler, 2003). Current and future users of the system should actively participate in its co-creation to consider their preferences (Simonofski et al., 2019). Each symbol, icon, colour, line, highlight, distance and size of an element should be justified and should not be used unnecessarily, as everything mentioned greatly affects the behaviour and perception of the web interface (Lidwell et al., 2010; Čermák, 2017). Users from different cultures evaluate various website interface features in different ways (Tsikriktsis, 2002). Many researchers focus on issues involved in designing an e-government interface within the context of a particular country (Kumar et al., 2021; Zhao, 2013; Nguyen, 2016; Khalil, 2011). Aladwani (2013) proves from his findings that a successful e-government website cannot be developed while ignoring factors of the national culture. Furthermore, he emphasizes the importance of aesthetic quality for creating favourable user attitudes towards a website. In his thesis on methodology for website localization from the perspective of web design, Čermák (2017) emphasizes the need to relate web design to values of culturally relevant dimensions. A Czech website should bear the following features in particular: high uncertainty avoidance (organized information hierarchy, linear navigation, position display on the site, site map, search, clear and sophisticated navigation, use of colours, user support) and high long-term orientation (lots of information on the homepage, content can be organised around the main area) (Čermák, 2017).

\section{Research Methods}

The research uses the principles of sequential mixed method design (Mihas, 2019; Berman, 2017; Schoonenboom and Johnson, 2017; Cronholm and Hjalmarsson, 2011; Teddlie and Tashakkori, 2010; Teddlie and Tashakkori, 2006), where findings of qualitative research are used to define relevant properties of web design to be evaluated in quantitative surveys. Qualitative research consists of focus groups and individual interviews.

\subsection{Context}

The Ministry of Finance is a central financial body, which is part of the executive branch. It is subordinate to the Government and it is headed by a member of the Government - the Minister of Finance. The Financial Administration is a system of administrative bodies of the Czech Republic intended for tax administration and subordinate to the Ministry of Finance. It consists of the following authorities with nationwide coverage: General Finance Directorate, Appellate Finance Directorate, and Tax Authorities. The Czech Financial Administration is established by Act no. 456/2011 Coll., on the Financial Administration of the Czech Republic.

Bonus compensation laws were adopted in connection with the crisis measures following the spread of coronavirus. Compensation bonuses were intended to mitigate the negative effects of government restrictions on the activities of the self-employed whose gainful activity was completely or partially reduced as a result of those restrictions. Persons who met the statutory conditions could apply for different financial amounts of the compensation bonus over nine different time periods from 5 October 2020 to 30 April 2021. 


\subsection{Focus group and interview}

Selected characteristics of evaluation of applications were obtained from stimuli from in-depth group discussions. One of them was a standard focus group of 90 minutes, which was attended by five entrepreneurial students aged 20-25. It was an open discussion led by the author of the article in a spacious informal room on the topic of requirements for tax information support. To evoke a pleasant and relaxed mental feeling, small refreshments and gifts were provided for the respondents. In order not to distort the information from the group discussion due to the influence of an opinion-oriented group of people, the respondents were selected at random and did not know each other in advance. At the same time, they had encountered the fulfilment of tax duties in their business practice, and they had experience with the design of the Financial Administration interface.

During the collective debate, the current state of interfaces for completing the tax return was discussed (Question: Which interfaces for completing the tax return do you know and what is your opinion on the current state of design of those interfaces?). Design and functional improvements to ensure appropriate e-administration applications were proposed (Question: Would you suggest any design and functional changes?). Respondents also expressed their views on specific elements and features of the interface they would embrace (open discussion on changes recommended in the previous question). The purpose of the interview was, among other things, to define in which direction the web interface of the Financial Administration and the Tax Portal should be oriented (showing the design of the current applications of the Financial Administration on a large screen, with the additional question: What direction should the visual interface design take in future?).

The questions for the respondents were asked by the focus group moderator in a neutral way, to obtain spontaneous answers, opinions and attitudes regarding the main topic. At the end of the discussion, the theoretical basis and the resulting categories and subcategories were verified by questions. The results of the qualitative survey are also based on information from an in-depth interview with the Head of the Services Development Department of the General Finance Directorate of the Czech Republic. The questions corresponded to those in the focus group, with the addition of questions about current plans, system suppliers, research carried out by the General Finance Directorate and application development processes in the institution. The focus group discussion and the interview were recorded, transcribed and analysed to find common occurrences of the same opinions related to set categories. The author examined the data closely to identify common themes. Patterns of meanings, ideas and topics that came up repeatedly across the data were identified using thematic analysis (implementation process: categories samples - coding).

\subsection{Questionnaire survey}

The chosen design features of the interfaces to evaluate in the questionnaire survey were based on the results of the qualitative survey. The selection of respondents took place by self-collection using a snowball sampling on social networks and mailing. Respondents' participation was completely voluntary. Respondents evaluated visual design of two web interfaces: (a) the Tax Administration's Tax Portal (see Appendix A and Appendix B) and (b) the application for a self-employed compensation bonus (see Appendix C and Appendix D). As regards the evaluation process, the questionnaire contained the same page previews as in the Appendices in the form of screenshots and a link to click to access the websites. Clicking the link was not a condition for completing the questionnaire, so the results correspond mainly to the evaluation of the visual design previews. The aim was not to test the usability and interactivity of the interface, but to find out the perception of the properties evoked by the visual design and arrangement of the elements of the website layout. The respondents expressed their perception of five qualitatively selected elements of web interfaces on a Likert scale yes - rather yes - do not know rather no - no. According to their level of agreement, they completed the statement "I consider the 
application design to be: clear / user friendly / modern / simple / convenient for ordinary users". The questionnaire also contained optional open-ended questions that are not part of the hypothesis testing and which serve to give the author deeper insight into the issue (Questions: How does the interface design of the Tax Portal/application for the compensation bonus affect you? What do you see as its strengths and weaknesses? How do you find the communication of the Tax Administration regarding the application for the compensation bonus for self-employed persons? What do you see as its strengths and weaknesses? How do you evaluate the communication of the "twenty-five for self-employed persons" compared to other communication and presentation of information by the Financial Administration?).

The dataset of the questionnaire survey consists of 76 answers, nationally $86 \%$ Czechs, $13 \%$ Slovaks and $1 \%$ others, demographically $84 \%$ women and $16 \%$ men. In terms of long-term residence, a relatively even distribution was achieved: $35 \%$ respondents from the capital city of Prague, $41 \%$ from a city or town (with a population over 3,001 ) and $24 \%$ from a small municipality (with a population up to 3,000). For the interpretation of the results, it is also important to note the predominance of answers by respondents aged $18-25$ years $(67 \%)$ and $26-35(21 \%)$ with complete secondary education by graduation $(51 \%)$ and university education (35\%). $80 \%$ of the respondents are not entrepreneurs, so they assessed interface design without previous experience and knowledge. Among the remaining $20 \%$ of self-employed persons, $11 \%$ of the respondents have performed their activities for more than 5 years.

The data were adjusted according to the content and absence of answers in some of the evaluated areas. Likewise, illogical and unrelated responses were excluded. The verbal scales of attitudes were converted to numbers: yes (1) - rather yes (2) - I do not know (3) - rather no (4) - no (5). Independent opinions on applications were then compared according to the individual five qualitative attributes using a paired $t-$ test to the mean value at the level of significance $\alpha=0.05$, testing the following hypotheses:

- $\mathrm{H}_{0}$ : There is no different perception of clarity (H1) / user friendliness (H2) / modernity (H3) / simplicity (H4) / suitability of design of the user interface of Financial Administration applications (H5) offered before the pandemic and developed during the pandemic.

- $\mathrm{H}_{1}$ : There is a different perception of clarity (H1) / user friendliness (H2) / modernity (H3) / simplicity (H4) / suitability of design of the user interface of Financial Administration applications (H5) offered before the pandemic and developed during the pandemic.

The statistical analysis was done in Gretl, version 2020d. Jarque-Bera and Doornik-Hansen tests were used to test the normal distribution of variables before performing a paired t-test. Due to short, no tails distributions and more than 50 responses (Frain, 2007) it was possible to use the Jarque-Bera test. The results of the normal distribution were also verified using the Doornik-Hansen test.

\section{Solutions and Results}

From the qualitative survey in the form of a focus group and an interview, information was obtained to select aspects of the interface to be evaluated afterwards in the questionnaire. Table 1 shows the five main themes, which emerged from the thematic analysis: clarity, user friendliness, modernity, simplicity and convenient design for ordinary users. The second column shows a summary of the recommendations that were cited most frequently in that category. In the third column, the author has selected strong quotes that describe the most common feelings and opinions in the theme. 
Table 1. Quotes for qualitative themes.

\begin{tabular}{l|l|l} 
Theme & Summary of Theme & Quote \\
\hline Clarity & $\begin{array}{l}\text { The portal should provide } \\
\text { comprehensible texts and a simple, clear } \\
\text { arrangement of design elements. }\end{array}$ & $\begin{array}{l}\text { "The notes and texts in the online tax form are too formal } \\
\text { and official, I do not understand them." }\end{array}$ \\
\hline User friendliness & $\begin{array}{l}\text { The portal should provide users with an } \\
\text { easy, effortless and pleasant experience. }\end{array}$ & $\begin{array}{l}\text { "Compared to filling out returns with private companies, it } \\
\text { scares me that I would sometimes have to click through } \\
\text { incomprehensible forms on the tax portal." }\end{array}$ \\
\hline Modernity & $\begin{array}{l}\text { The portal and information should be } \\
\text { constantly updated and adapted to new } \\
\text { trends. }\end{array}$ & $\begin{array}{l}\text { The website design is very old-fashioned, and the Financial } \\
\text { Admintion is aware of the need to modify it." }\end{array}$ \\
\hline Simplicity & $\begin{array}{l}\text { The portal should follow universal design } \\
\text { principles (clean layout, few colour } \\
\text { schemes, white space, highlighting } \\
\text { important point, etc.). }\end{array}$ & $\begin{array}{l}\text { "I fees not work yet, I am completely lost." } \\
\text { deelmed with information and when the search }\end{array}$ \\
\hline $\begin{array}{l}\text { Convenient design } \\
\text { for ordinary users }\end{array}$ & $\begin{array}{l}\text { The portal should focus also on users } \\
\text { without technical experience and with } \\
\text { different types of education. }\end{array}$ & $\begin{array}{l}\text { "Melp parents or grandparents would definitely need me to } \\
\text { heven be able to sign up." }\end{array}$
\end{tabular}

The exact distribution of rating scales of the adjusted data set of 67 respondents are shown in Figure 1.

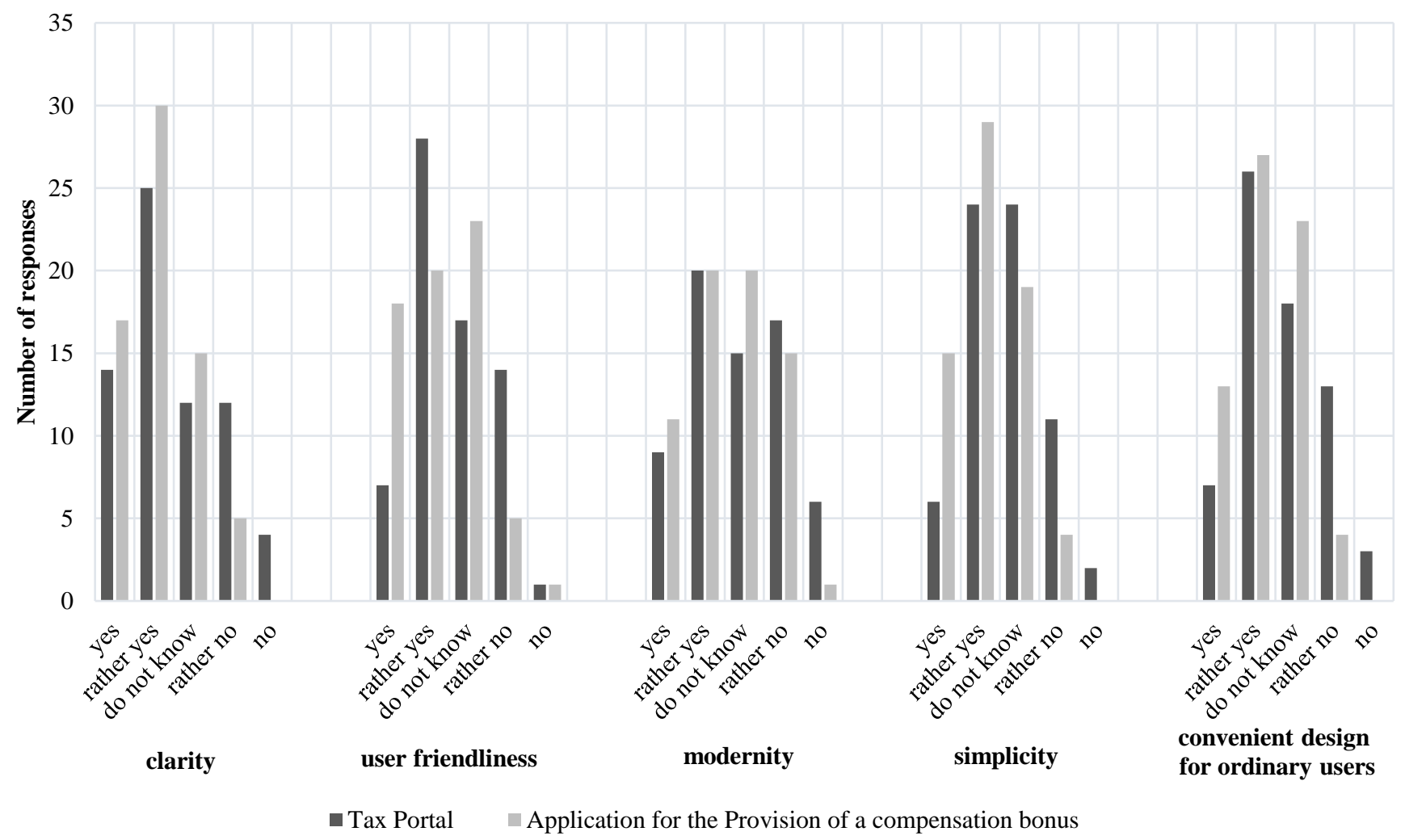

Figure 1. Comparison of results of evaluated attributes of Financial Administration applications.

The Jarque-Bera test and the Doornik-Hansen test showed normal distribution of the variables. Only for the variable Clarity, the p-value based on Doornik-Hansen rejected the null hypothesis of a normal distribution, but according to the Jarque-Bera test, the sample was found to be normally distributed. Based on this assumption, paired t-tests were subsequently performed. 
The following enumeration and Table 2 present the results of the verification of hypotheses, with a 95\% probability when confirming the difference, for five interface features of two different Financial Administration applications examined by the quantitative survey.

H1: At the level of significance $\alpha=0.05$, the null hypothesis is rejected. The alternative $\mathrm{H}_{1}$ : There is a different perception of the clarity of the user environment of the Financial Administration applications offered before the pandemic and developed during the pandemic.

H2: At the significance level $\alpha=0.05$, the null hypothesis is rejected. The alternative $\mathrm{H}_{1}$ : There is a different perception of the user-friendliness of the Financial Administration applications offered before the pandemic and developed during the pandemic.

H3: At the level of significance $\alpha=0.05$, the null hypothesis is not rejected. The alternative $\mathrm{H}_{0}$ : There is no different perception of the modernity of the user environment of the Financial Administration applications offered before the pandemic and developed during the pandemic.

H4: At the significance level $\alpha=0.05$, the null hypothesis is rejected. The alternative $\mathrm{H}_{1}$ : There is a different perception of the simplicity of the user environment of the Financial Administration applications offered before the pandemic and developed during the pandemic.

H5: At the level of significance $\alpha=0.05$, the null hypothesis is rejected. The alternative $\mathrm{H}_{1}$ : There is a different perception of the suitability of designing Financial Administration applications for ordinary users offered before the pandemic and developed during the pandemic.

Table 2. Paired samples t-test results.

\begin{tabular}{l|c|c|c|c|c|c}
\multirow{2}{*}{ Variables } & \multicolumn{2}{|l|}{ Tax Portal } & \multicolumn{2}{|l|}{$\begin{array}{l}\text { Application for the provision of } \\
\text { a compensation bonus }\end{array}$} & \multirow{2}{*}{ t-value } & p-value \\
\cline { 2 - 7 } & Mean & Std. deviation & Mean & Std. deviation & & \\
\hline H1: Clarity & 2.51 & 1.19 & 2.12 & 0.88 & 2.63 & 0.01 \\
\hline H2: User friendliness & 2.61 & 0.98 & 2.27 & 0.99 & 2.27 & 0.03 \\
\hline H3: Modernity & 2.87 & 1.20 & 2.63 & 1.06 & 1.28 & 0.21 \\
\hline H4: Simplicity & 2.69 & 0.96 & 2.18 & 0.85 & 4.01 & 0.00 \\
\hline $\begin{array}{l}\text { H5: Convenient design } \\
\text { for ordinary users }\end{array}$ & 2.69 & 1.05 & 2.27 & 0.84 & 2.96 & 0.00 \\
& & & & & &
\end{tabular}

\section{Discussion}

Improving website design such as navigation, accessibility, aesthetics, content and customization motivate the adoption of e-government by citizens (Chan and Almaghalsah, 2020). The interface of the application for the provision of a compensation bonus for self-employed persons uses appropriate design elements for easier orientation, a more intuitive environment for different types of users, as well as a more suitable arrangement and balance of the applied elements. To increase the success of an e-government system, the authorities have to develop systems that have a high level of usability, user-friendliness and ease of use (Stefanovic et al., 2016). The importance of the characteristics of user-friendliness, clarity and simplicity for users was confirmed by the performed thematic analysis. Respondents noticed different elements and design principles of the interfaces and evaluated their arrangement in the application for the provision of a compensation bonus positively, in accordance with the author's input assumptions. Only the aspect of modernity was not assessed differently, which could have arisen due to an unclear grasp of the meaning and its different possibilities of interpretation.

Fang (2002) describes successful features for concept, practice and development of e-government all around the world. From the point of view of design and usability, he emphasizes the need for transparency, ease of use and digital structure with an interface that simplifies and modernizes each 
transaction individually and the whole process of administration in general (Fang, 2002). Navigation facilities and accessibility of tax e-administration were identified as important quality criteria of egovernment web sites (Saha et al., 2012). Additionally, Chen (2010) assesses the quality of the system and information according to its interactivity, ease of use and focus on accuracy, timeliness and sufficiency of information provided for citizens. Thanks to the simple design, appropriately selected functionalities and website layout, users complete their tax-related tasks with a minimum effort (Saha et al., 2012). Yeh and Lin (2008) examine the complex relationship between design elements and users' feelings.

Zhang and Zhang's (2020) design guideline based on tax compliance concepts and theories emphasize the functional elements of the user interface for tax collection. Thanks to the apparent separation of the tax from net income, it is possible to influence the feelings of taxpayers and increase tax compliance (Muehlbacher et al., 2017). User design should clearly distinguish individual tax transactions and the meanings of amounts, deductions, tax reliefs and bonuses by their location, size, text colours or highlighting. The application menu structure and interface style should be thought out carefully to simplify the taxpaying procedure as much as possible. At the same time, it is important to use exact and understandable names of buttons, symbols and labels, and detailed explanations, supplemented by a selfcorrection mechanism (Zhang and Zhang, 2020). The Czech Financial Administration has long been concerned with the problem of using strict legal tax terminology instead of transcribing it into a language more understandable to various types of taxpayers.

\subsection{Contribution to practice and theory}

The results are applicable at all levels of public administration. From the point of view of practice, this study primarily benefits the Financial Administration, the Ministry of Finance and other public state institutions. Understanding the importance of perceiving the user interface in the performance of civic duties has positive effects for all citizens. Knowledge of the preferred design can be used to develop other important applications that need to be widely used by citizens, such as the application eMask (eRouška in Czech) to report close positively tested contacts. The new design of the web application for a compensation bonus has even been already used to voluntarily apply for a flat tax at the beginning of 2021.

The results of testing of any e-government systems are important for their continuous development and improvement all around the world. New findings may confirm or help develop scientific knowledge in the field of design development. From the perspective of visual interface design, researchers and professionals such as GUI developers, UI designers and visual interface designers may obtain useful stimuli. Findings on human perceptions of user interface design may have a potentially multidisciplinary overlap in user psychology research.

\subsection{Assumptions and limitations}

The questions in the quantitative survey were not supplemented by items that could cause an unobservable latent variable. In a comparative study, it would be appropriate to incorporate a confrontation of the results of respondents who expressed a negative opinion on the word "taxes" with respondents holding a neutral opinion. The perceived satisfaction of respondents may be influenced by the negative attitude to the Financial Administration, assumptions and expectations, educational background, self-concepts, pre-conceived notions, bad past experience with the behaviour of officials, or cultural, socio-demographic and personal characteristics. Many researchers examine the influence of these factors on the acceptance of e-government and its use (Nam, 2014; Santhanamery and Ramayah, 2015; Venkatesh et al., 2014; Sipior et al., 2011).

Since the sample size and the survey did include probability sampling (a total of $85 \%$ of female respondents and $88 \%$ of respondents aged $18-35$ in the questionnaire) and the questionnaire completion 
was done online on a voluntary basis, it is not possible to generalize the paper results to all the citizens of the Czech Republic. The results of the survey are most representative of women aged 18-35 with secondary or university education. However, the given age category is essential for the development of Financial e-Administration system, as this generation has high requirements for user-centred web design and interfaces. They have higher demands on user friendliness and an appropriate level of digital interaction (Desai and Lele, 2017).

\section{Conclusions}

In response to the COVID-19 pandemic and the need to address sudden demands, the Czech Financial Administration has launched a new portal for sending applications for the payment of a compensation bonus. In the short term, the public institution was able to respond appropriately to the situation, as evidenced by $46 \%$ of the respondents who gladly accepted the innovative changes of the new visual interface design compared to the Tax Portal design. From 2003 to February 2021, the Tax Portal of the Financial Administration had not made use of the potential of technological opportunities and main universal design principles.

The paper compares the user evaluation of the Tax Portal application operating several years before the pandemic with the new portal for the application of a compensation bonus for self-employed persons. The results of the paired t-test confirmed on the new portal the positive perception of four out of the five examined properties: clarity, user-friendliness, simplicity and convenient design for ordinary users. Respondents consider the design of the application developed during the pandemic to be clearer, more user-friendly, simpler and more convenient for ordinary users. In the fifth element of the comparison of applications, modernity, the mean values of the first and second selection were almost identical. The respondents did not find the second application more modern. These results concerning the perception of application design bring significant findings for the future development of Financial e-Administration projects.

The digital human-centred transformation in Financial e-Administration and e-government is a long-term process and a complex challenge at multiple levels of government. Despite this, the author believes that if the state strategy goes in an innovative human-oriented direction, as it has done in the case of the application for provision of a compensatory bonus, electronic services will bring many positives to Czech citizens in execution of their life obligations towards the state.

The knowledge gained about changing perceptions of user interface design and layout elements is valuable for creating, testing and improving current and future public information interfaces for citizens. E-government designers can more precisely capture the perceived design quality of the application or website as evaluated by citizens. The results confirm the importance of design in users' perception and, at the same time, strengthen the validity of theoretical principles in the field of visual interface design.

It would be appropriate to follow up the research with an additional quantitative survey focused on agediverse and more mixed-gender respondents in order to ensure greater representativeness and applicability of the survey results to the citizens of the Czech Republic. As part of the experimental investigation, I would recommend testing positive and negative visual design elements and accessibility for disadvantaged users by means of assistive technologies. The case study method and usability testing such as PSSUQ could also yield interesting results, according to which a new interface would be designed, discussed, prototyped and tested. 


\section{Additional Information and Declarations}

Acknowledgements: I would like to extend my gratitude to Zdeněk Smutný. His enthusiasm, knowledge and exacting attention to detail have been an inspiration and kept my work on track from my first encounter to the final draft of this paper.

Conflict of Interests: The author declares no conflict of interest.

Author Contributions: The author confirms being the sole contributor of this work.

Data Availability: The data that support the findings of this study are available from the corresponding author.

\section{Appendix A}

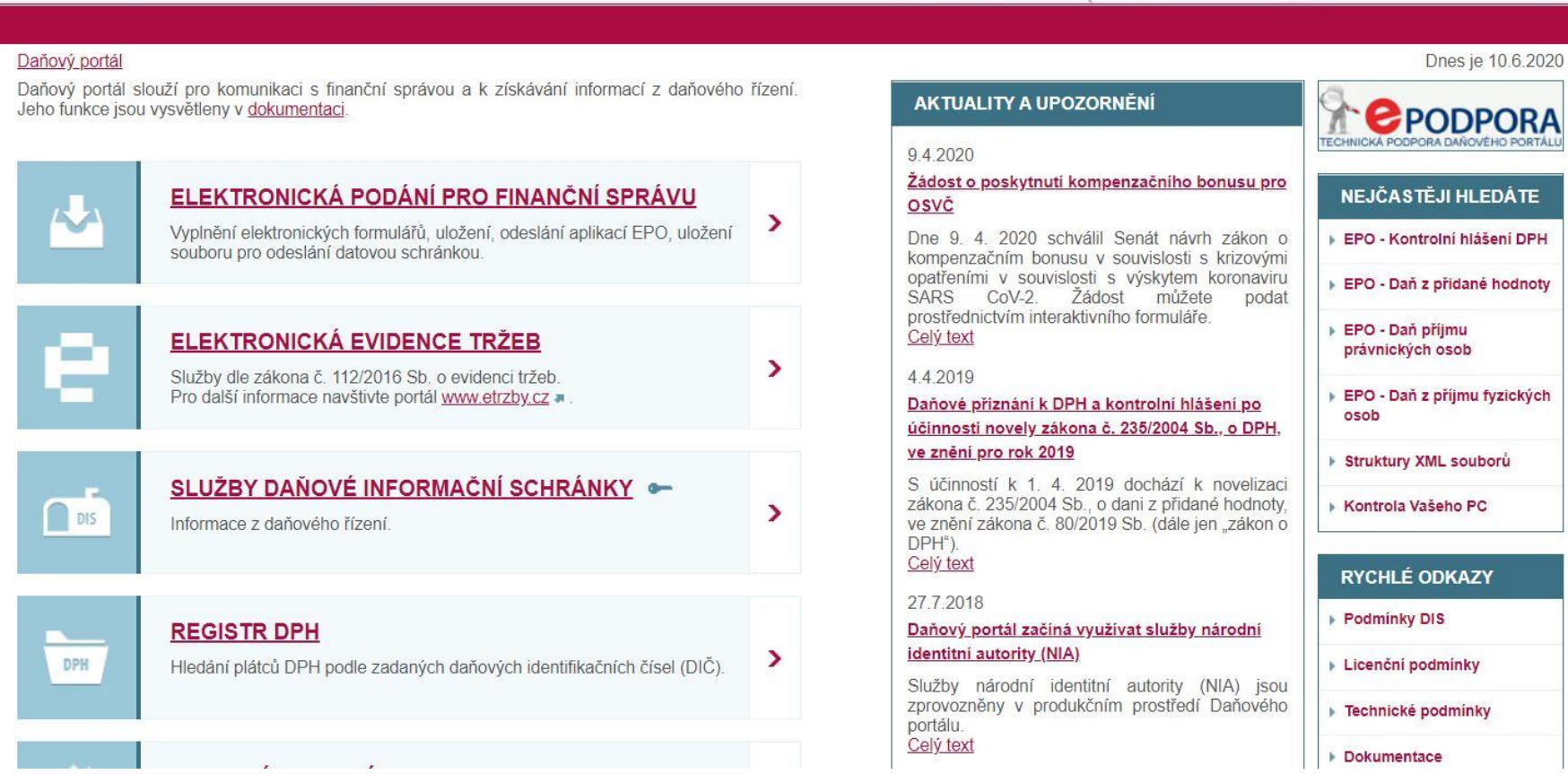

Figure A1. Tax Portal interface (dashboard). 


\section{Appendix B}

\section{OPUSTIT}

FORMULÁR

\section{ODDÍL - Údaje o poplatníkovi}

Identifikace dan̆ového subjektu

Daňové identifikační číslo (pouze číselná část) (?) Rodné číslo. (?)

$\mathrm{CZ}$

Přĭjmeni (??)

Rodnép řijmení(?)

Státníp ríslušnost.(?)

Adresa místa pobytu v den podání DAP

Ulice/část obce Číslo popisné Číslo orientační

Obec / Městská část (vyberte z čiselniku pomocí následujicího tlačítka) PSČ (vyberte z číselníku por Vybrat Vybrat

Stát (vyberte z číselníku v následujicím poličku). (?)

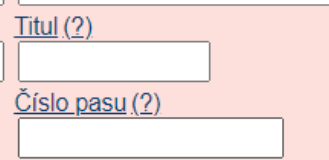

Kontaktní informace

Telefon/mobilní telefon (?).
PRO STRÁNKU:

Pr̃edchozi stránka

Dalši stránka

Kontrola stránky

Prepočet

PRO CELÝ FORMULÁŔ:

Protokol chyb

Prưvodce

Načteni souboru

Uložení prac. souboru

Uloženi k odeslání

do Datové schránky

Odesláni pisemnosti

\section{Úplný opis $k$ tisku}

\begin{tabular}{l|} 
StráNKY \\
\hline Úvod \\
Záhlaví \\
I. Oddíl \\
II. Oddíl \\
III. Oddil \\
IV. Oddil \\
V. Oddil \\
\hline VI. Oddil \\
\hline
\end{tabular}

Figure B1. Tax Portal interface (income tax return dashboard).

\section{Appendix C}

IIF Žádost o poskytnutí kompenzačního bonusu (KB V.)

Požadovaná část

Předmětná činnost

Údaje o żadateli

Údaje k podáni

Čestné prohlášen
$\mathbf{A}$
Požadovaná částka

této části nejdřive zodpovězte dotazy, které určí, za které bonusové období je Vám ještě povoleno žáda

Informace $\mathrm{k}$ datům, do kdy můžete žádat, naleznete v nápovědě. Dále zvolte typ subjektu a zadejte období, za které o kompenzační bonus žádáte.

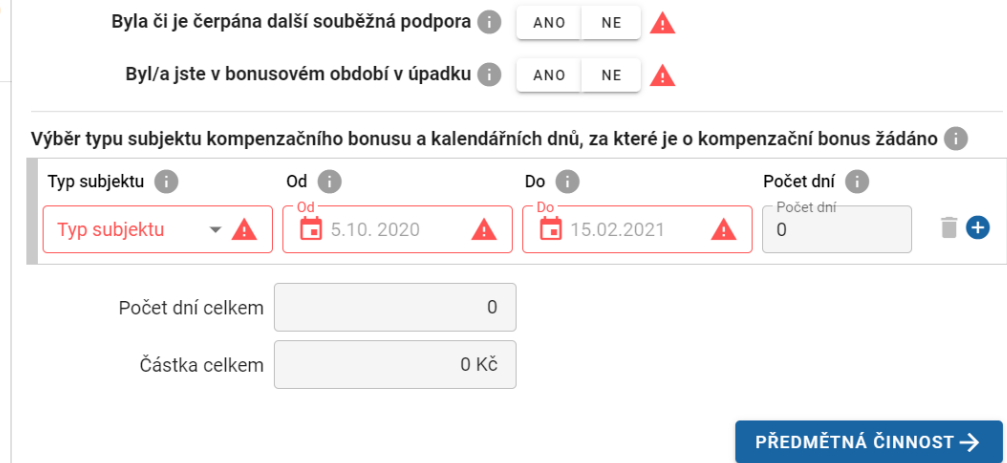

$\square$ Podat $\mathbb{t}_{\downarrow}$ Import/Export $\odot$ Reset

Stav vyplnění

Vyplňte povinné údaje označené trojúhelníkem. Předvyplněnou hodnotu potvrd'te klepnutím na žluté kolečko.

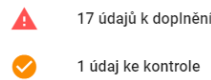

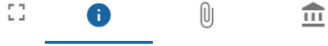

1. Požadovaná částka

Částka kompenzačního bonusu, na kterou Vám vznikl nárok, a žádáte o její prizznání a vyplacení. Výše kompenzačniho bonusu činí $500 \mathrm{Kc}$ za kalendăñí den.

Žádost Ize obecně podat nejpozději do 5.1. 2021 pro První bonusové období, do 22. 1. 2021 pro Druhé bonusové období, do 15. 2. 2021 pro Třetí bonusové období, do 25. 2. 2021 pro čturté bonusové období, do období, do 25. 2. 2021 pro Čturté bonusové obdobi, do pro Šesté bonusové obdobi.

Figure C1. Application for a self-employed compensation bonus (dashboard). 


\section{Appendix D}

Požadovaná částka

$V$ této části nejdřive vyberte, zda budete žádost o kompenzační bonus vyplňovat jako osvč nebo jako společník společnosti s ručením omezeným. Dále vyplňte období, za které požadujete výplatu kompenzačního bonusu. Prvním bonusovým obdobím je období od 12. 3. 2020 do 30. 4. 2020. Druhým bonusovým obdobím je období od 1. 5.2020 do 8. 6. 2020. Období je možné zadat obě najednou (tj. od 12. 3. 2020 do 8. 6. 2020) nebo i na více částí (např. od 12. 3. 2020 do 23.5. 2020 a od 1. 6. 2020 do 8. 6. 2020)

Vyberte subjekt kompenzačního bonusu:
OSVČ - osoba samostatně výdělečně činná

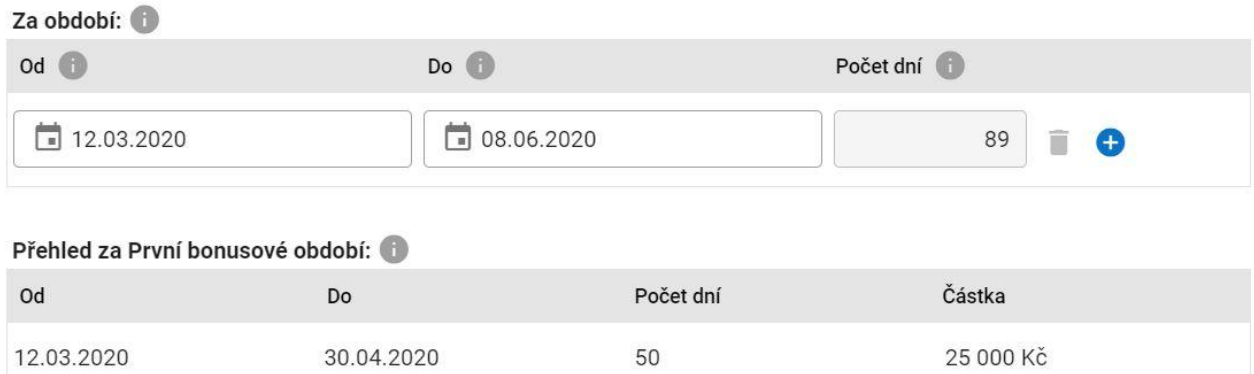

Figure D1. Application for a self-employed compensation bonus (completion procedure).

\section{References}

Abu-Shanab, E., \& Harb, H. (2019). E-Government Research Insights: Text Mining Analysis. Electronic Commerce Research and Applications, 38, no. 100892. https://doi.org/10.1016/i.elerap.2019.100892

Aladwani, A. M. (2013). A cross-cultural comparison of Kuwaiti and British citizens' views of e-government interface quality. Government Information Quarterly, 30(1), 74-86. https://doi.org/10.1016/j.giq.2012.08.003

Barnes, S. J., \& Vidgen, R. (2004). Interactive e-government services: modelling user perceptions with eQual. Electronic Government, 1(2), 213-228. https://doi.org/10.1504/EG.2004.005179

Berman E. A. (2017). An Exploratory Sequential Mixed Methods Approach to Understanding Researchers' Data Management Practices at UVM: Findings from the Qualitative Phase. Journal of eScience Librarianship, 6(1). https://doi.org/10.7191/jeslib.2017.1097

Čermák, R. (2017). Methodology for website localization from the point of view of web design. Dissertation. University of Economics, Prague.

Havlíček, K. (2021, May 12-13). Digital Czechia 2021 [Conference presentation]. https://www.politikaspolecnost.cz/video/digitalni-cesko-2021-12-kvetna/

Chan, C. H., \& Almaghalsah, H. (2020). Usability evaluation of e-government websites: A case study from Taiwan. International Journal of Data and Network Science, 4(2), 127-138. https://doi.org/10.5267/j.ijdns.2020.2.004

Chen, C. (2010). Impact of quality antecedents on taxpayer satisfaction with online tax-filing systems - an empirical study. Information \& Management, 47, 308-315. https://doi.org/10.1016/.j.im.2010.06.005

Cronholm, S., \& Hjalmarsson, A. (2011). Experiences from sequential use of mixed methods. The Electronic Journal of Business Research Methods, 9(2), 87-95.

Desai, S. P., \& Lele, V. (2017). Correlating internet, social networks and workplace - a case of generation Z students. Journal of Commerce and Management Thought, 8(4), 802-815. https://doi.org/10.5958/0976-478X.2017.00050.7

eGovernment and Trust. (2020). eGovernment Benchmark 2020: EGovernment that works for the people. Shaping Europe's Digital Future - European Commission. https:/lec.europa.eu/digital-single-market/en/news/egovernment-benchmark2020-egovernment-works-people

Fang, Z. (2002). E-government in digital era: concept, practice, and development. International Journal of the Computer, the Internet and management, 10(2), 1-22.

Frain J. C. (2007). Small sample power of tests of normality when the alternative is an alpha-stable distribution. Trinity Economics Papers, 0207, Trinity College Dublin, Department of Economics. 
Hoppe, T., Schanz, D., Sturm, S., \& Sureth-Sloane, C. (2019). Measuring Tax Complexity Across Countries: A Survey Study on MNCs. TRR 266 Accounting for Transparency Working Paper Series, 5. WU International Taxation Research Paper Series, 6. https://doi.org/10.2139/ssrn.3469663

Khalil, O. E. (2011). e-Government readiness: Does national culture matter? Government Information Quarterly, 28(3), 388399. https://doi.org/10.1016/i.giq.2010.06.011

Kumar, S., Baishya, K., Sreen, N., Sadarangani, P. H. \& Samalia, H. V. (2021). Impact of National Culture on E-Government Development. Journal of Global Information Management, 29 (2), 1-22. https://doi.org/10.4018/jgim.2021030101

Kumar, V., Mukerji, B., Butt, I., \& Persaud, A. (2007). Factors for successful e-government adoption: A conceptual framework. Electronic Journal of E-government, 5(1).

Lidwell, W., Holden, K., Butler J., \& Elam, K. (2010). Universal Principles of Design: 125 Ways to Enhance Usability, Influence Perception, Increase Appeal, Make Better Design Decisions, and Teach Through Design. Rockport Publishers.

Mihas, P., \& Odum Institute (2019). Learn to use an exploratory sequential mixed method design for instrument development. SAGE Publications, Ltd. https://doi.org/10.4135/9781526496454

Muehlbacher, S., Hartl, B., \& Kirchler, E. (2017). Mental accounting and tax compliance: Experimental evidence for the effect of mental segregation of tax due and revenue on compliance. Public Finance Review, 45(1), 118-139. https://doi.org/10.1177/1091142115602063

Nam, T. (2014). Determining the Type of E-Government Use. Government Information Quarterly, 31(2), $211-220$. https://doi.org/10.1016/i.giq.2013.09.006

Nguyen, N. (2016). A cross-cultural study on e-government services delivery. Electronic Journal Information Systems Evaluation, 19 (2), 121-134.

Petráček, V. (2021, May 12-13). Digital Czechia 2021 [Conference presentation]. https://www.politikaspolecnost.cz/video/digitalni-cesko-2021-12-kvetna/

Saha, P., Nath, A. K., \& Salehi-Sangari, E. (2012). Evaluation of government e-tax websites: An information quality and system quality approach. Transforming Government: People, Process and Policy, 6(3), 300-321. http://doi.org/10.1108/17506161211251281

Santhanamery T. \& Ramayah, T. (2015). Understanding the effect of demographic and personality traits on the e-filing continuance usage intention in Malaysia. Global Business Review, 16(1), 1-20. https://doi.org/10.11770972150914553459

Schoonenboom, J. \& Johnson, R. B. (2017). How to Construct a Mixed Methods Research Design. KZfSS Kölner Zeitschrift für Soziologie und Sozialpsychologie, 69, 107-131. https://doi.org/10.1007/s11577-017-0454-1

Simonofski A., Snoeck M., \& Vanderose B. (2019). Co-creating e-Government Services: An Empirical Analysis of Participation Methods in Belgium. In R. Bolivar, \& M. Pedro (Eds.), Setting Foundations for the Creation of Public Value in Smart Cities. Public Administration and Information Technology (pp. 225-245). Springer. https://doi.org/10.1007/978-3319-98953-2 9

Sipior J. C., Ward, B. T., \& Connolly, R. (2011). The digital divide and t-government in the United States: using the technology acceptance model to understand usage. European Journal of Information Systems, 20(3), pp. 308-328. https://doi.org/10.1057/ejis.2010.64

Stefanovic, D., Marjanovic, U., Delić, M., Culibrk, D., \& Lalic, B. (2016). Assessing the success of e-government systems: An employee perspective. Information \& Management, 53(6), 717-726. https://doi.org/10.1016/j.im.2016.02.007

Teddlie, C. \& Tashakkori, A. (2010). Overview of contemporary issues in mixed methods research. In Tashakkori, A. \& Teddlie, C. (Eds.), Sage Handbook of Mixed Methods in Social \& Behavioral Research, (pp. 1-41). Sage.

Teddlie, C. \& Tasshakori, A. (2006). A general typology of research designs featuring mixed methods. Research in the Schools, 13(1), 12-28.

Tsikriktsis, N. (2002). Does culture influence web site quality expectations? An empirical study. Journal of Service Research, 5(2), 101-112. https://doi.org/10.1177/109467002237490

Venkatesh V., Sykes T. A., \& Venkatraman S. (2014). Understanding e-Government portal use in rural India: role of demographic and personality characteristics. Information Systems Journal, 24(3), 249-269. https://doi.org/10.1111/isj.12008

Wimmer M. A., \& Holler U. (2003). Applying a Holistic Approach to Develop User-Friendly, Customer-Oriented E-Government Portal Interfaces. In N. Carbonell, \& C. Stephanidis (Eds.), Universal Access Theoretical Perspectives, Practice, and Experience. UI4ALL 2002 (pp. 167-178). Springer. https://doi.org/10.1007/3-540-36572-9 13

Yeh, C.-H., Lin, Y.-C. (2008). User-centered design of web pages. In Gervasi, O. et al. (Eds.), Computational Science and Its Applications. ICCSA 2008 (pp. 129-142). Springer. https://doi.org/10.1007/978-3-540-69848-7 12

Zhang B., \& Zhang J. (2020). Design Suggestions for Smart Tax Return Software Based on Reviewing Tax Compliance Literature. In Stephanidis C. et al. (Eds.), HCI International 2020 - Late Breaking Papers: Cognition, Learning and Games. HCll 2020 (pp. 150-161). Springer. https://doi.org/10.1007/978-3-030-60128-7 12

Zhao, F. (2013). An empirical study of cultural dimensions and e-government development: implications of the findings and strategies. Behaviour \& Information Technology, 32(3), 294-406. https://doi.org/10.1080/0144929X.2011.644580 
Editorial record: The article has been peer-reviewed. First submission received on 12 March 2021. Revisions received on 20 March 2021, 7 June 2021, and 31 August 2021. Accepted for publication on 14 October 2021. The editor in charge of coordinating the peer-review of this manuscript and approving it for publication was Miloslav Hub (D).

Acta Informatica Pragensia is published by Prague University of Economics and Business, Czech Republic.

ISSN: 1805-4951 